\title{
Pembangunan Hukum Bisnis Dalam Perspektif Pancasila Pada Era Revolusi Industri 4.0
}

Soesi Idayanti

Fakultas Hukum Universitas Pancasakti Tegal

soesi.idayanti@gmail.com

Suci Hartati

Fakultas Hukum Universitas Pancasakti Tegal

heycik@yahoo.co.id

Toni Haryadi

Fakultas Hukum Universitas Pancasakti Tegal

toniharyadi54@gmail.com

DOI: $10.23917 /$ jjr.v9i1.8091

\section{Submission \\ Track: \\ Received: \\ 1 Mei 2019 \\ Final Revision: \\ 15 Juni 2019 \\ Available online: \\ 30 Juni 2019 \\ Corresponding \\ Author: \\ Soesi Idayanti \\ soesi.idayanti@gmail.com

\begin{abstract}
Tujuan: Artikel ini bertujuan untuk merumuskan pembangunan hukum bisnis dalam perspektif Pancasila pada era revolusi industri 4.

Metodologi: Metode penelitian yang digunakan adalah metode penelitian yuridis normatif tentang implementasi ketentuan hukum positif secara in action dalam hokum bisnis di era revolusi Industri 4.0. Jenis dan sumber data yaitu meliputi data primer dan data sekunder yang didapat melalui sumber hukum primer yang terdapat dalam beberapa produk hukum yang berkaitan dengan bisnis dan perdagangan.
\end{abstract} \\ Temuan: Perkembangan globalisaasi yang semakin pesat yang ditandai oleh era revolusi industri abad ke-21 saat ini membawa perubahan besar-besaran di berbagai bidang baik bidang hukum, politik, ekonomi, bisnis, teknologi, sosial, budaya. Revolusi industri 4.0 yang ditandai dengan pemanfaatan bidang-bidang telematika ( telekomunikasi, media dan informasi )perlu adanya penyesuaian terhadap regulasi di bidang hukum bisnis.}

Kegunaan: Pemerintah Indonesia perlu melakukan pembangunan hukum dibidang perdagangan / bisnis dalam bentuk pengembangan hukum, harmonisasi hukum maupun melakukan rekonstruksi hokum dalam rangka pembaharuan produk hukum dengan membangun suatu sistem hokum sesuai dengan situasi global untuk menyesuaikan dengan era industri 4.0 dengan mencerminkan dan bersumber pada Pancasila dan UUD 1945.

Kebaruan/Orisinalitas: Pembangunan hukum bisnis dalam era Industri 4.0 dengan segala kecanggihan dan seluruh rangkaian proses industrialisasi harus sejalan dengan nilai Pancasila dan UUD 1945. 


\section{PENDAHULUAN}

Arnold Toynbee dalam bukunya Lectures On The Industrial Revolution adalah orang yang pertama kali mencetuskan istilah revolusi industri ${ }^{l}$. Istilah Revolusi Industri yang sekarang sangat familiar bagi kita saat ini sudah berada pada revolusi industri ke empat / era industri 4.0. Revolusi industri 4.0 sekarang ini telah melewati tahapan dengan adanya revolusi industri terdahulu . Diawali dengan ditemukannya mesin uap oleh James Watt pada tahun 1784 sebagai pencetus dimulainya revolusi industri pertama . Dilanjutkan dengan penemuan listrik pada tahun 1870 sebagai perintis industri kedua, dan selanjutnya munculnya media computer sebagai langkah dalam menghadapi revolusi industri ketiga, dan sampai saat ini di awal abad 21 dimana globalisasi juga muncul bersamaan dengan penggunaan ilmu dan teknologi secara luas dalam internet dan Teknologi Informasi (TI) sebagai pemicu revolusi industri 4.0.

Telekomunikasi adalah kekuatan penggerak yang secara serentak menciptakan ekonomi global untuk bersaing didalam pasar yang benar-benar cosmopolitan. Dalam revolusi industri ke-empat pada abad 21 inilah terjadinya perubahan besar-besaran diberbagai bidang tersebut yang mampu mengurangi sekat-sekat antara dunia fisik, digital dan biologi. ${ }^{2}$ Pada awal abad ke duapuluh satu inilah semua kemampuan komunikasi yang mungkin akan kita butuhkan ada digenggaman kita.

Ketika sebuah jangkauan komunikasi sudah berkembang sangat luas maka ini dapat dijadikan sebagai suatu pilar dalam perdagangan dan bisnis baik dalam skala nasional maupun skala internasional. Masyarakat modern yang biasa disebut dengan istilah modern society berada dalam era teknologi informasi yang saat ini popular disebut dengan "disruption era" atau era revolusi industry 4.0. Artinya dunia global telah menempatkan kehidupan manusia di era industri 4.0 ini berada di tengah-tengah arus teknologi yang begitu cepat perkembangannya yang bersifat positip dan maupun bersifat negative yang menjadi ancaman bagi kehidupan manusia. Kehidupan dunia usaha dan bisnis yang didukung teknologi informasi seperti internet telah menciptakan dunia bisnis seolah-olah tanpa batas (bordeless trade) di seluruh penjuru dunia. Kemajuan ini secara otomatis baik langsung maupun tidak langsung telah berimplikasi pada eksistensi hukum yang mengaturnya. ${ }^{3}$

\footnotetext{
${ }^{1}$ Arnold Toynbee, 1884, Lecturer on the Industrial Revolution, London.

2 The Fourth Industri Revolution : Economic Forum, diakses tgl 20 maret 2019

${ }^{3}$ M Arsyad Sanusi, Antisipasi cybercrime dan efektivitas UU ITE, jurnal Hukum Bisnis, Vol 29 Tahun 2010
} 
Erni R Ernawan mengemukakan bahwa prinsip-prinsip dalam berbisnis pada dasarnya harus mencerminkan etika yang meliputi lima prinsip yaitu : (1) otonomi, (2) kejujuran, (3) keadilan, (4) saling menguntungkan dan (5) integritas moral . Berbeda dengan Caux Round Table : Principles for Business, penerapan prinsip-prinsip umum bisnis meliputi 7 prinsip yaitu (1) tanggung jawab, (2) dampak ekonomi dan social bisnis, inovasi, keadilan dan masyarakat dunia, (3) perilaku bisnis, (4) menghargai peraturan, (5) mendukung perdagangan multilateral, (6) menghormati lingkungan dan (7) menghindari praktek-praktek yang kotor. ${ }^{4}$

Dinamika pembangunan Indonesia yang dipicu dengan perkembangan dan kemajuan ilmu pengetahuan dan teknologi yang saat ini telah memasuki era industri 4.0 membawa perubahan pada perkembangan perdagangan yang saat ini dapat dilakukan dengan secara elektronik dengan melalui digital elektronik,, artificiala intelligence, big data, robotic. Akan tetapi perkembangan teknologi ini dapat dikatakan sebagai sebuah pedang bermata dua, dimana disatu sisi dapat memberikan kontribusi yang bersifat positip terhadap peningakatan kesejahteraan, kemajuan dan perubahan peradaban manusia yang menyebabkan hubungan dunia seoleh-oleh tanpa batas ( bordeless) dan hal ini dapat menyebabkan perubahan sosial,ekonomi dan budaya secara signifikan, peningkatan investasi perusahaan, peningkatan produktifitas dan kualitas sekaligus dapat menimbulkan pergeseran peran konvensional di dalam pasar, timbulnya persaainagan sengketa, timbulnya perbuatan melawan hukum pelaku usaha, penyelesaian sengketa, belum adanya kemampuan pemerintah dalam membuat regulasi model bisnis dengan teknologi baru, dan timbulnya fragmentasi sosial yang dapat berpotensi melebarkan ketimpangan ekonomi.

Satu hal yang pasti bahwa revolusi industri 4.0 telah datang ditengah-tengah kita dan kita tidak mungkin menolak atau menghindarinya . Proses ini akan terus berjalan ditengah kemampuan atau bahkan ketidakmampuan khususnya terhadap dampak negative yang mungkin ditimbulkan. Pembangunan hukum yang dilakukan oleh pemerintah harus merupakan suatu proses yang dinamis mengikuti tuntutan global dalam menghadapi kontradiksi dan dilema internassional yang dihadapi oleh masyarakat industrial,khususnya bidang perdagangan / bisnis. Tantangan bagi pemerintah dalam merespon perubahan revolusi era industri 4.0 dengan membangun hukum nasional yang berkepribadian Indonesia, yang dilandasi dasar falsafah dan ideologi Pancasila. Pembangunan hukum berbasis Pancasila dan

\footnotetext{
${ }^{4}$ Erni R.Ernawan, Business Ethics, Bandung, Alfabeta, 2007, hal 20-22
} 
UUD 1945 dalam menuju peradaban masyarakat bermartabat dihadapan pada berbagai tantangan dan pengaruh ideologi asing .

\section{METODOLOGI PENELITIAN}

Metode penelitian yang digunakan adalah metode penelitian yuridis normatif tentang implementasi ketentuan hukum positif secara in action dalam hokum bisnis di era revolusi Industri 4.0. Jenis dan sumber data yaitu meliputi data primer dan data sekunder yang didapat melalui sumber hukum primer yang terdapat dalam beberapa produk hukum yang berkaitan dengan bisnis dan perdagangan.

\section{PEMBAHASAN}

Globalisasi merupakan suatu proses kebudayaan, dimana ada kecenderungan wilayahwilayah di dunia menjadi satu dalam format social, politik dan ekonomi. Dalam proses situ seolah-olah tidak ada lagi wilayah dimanapun didunia ini yang dapat menghindar proses global. Globalisasi dibidang ekonomi yang sedang melanda seluruh dunia saat ini dapat diibaratkan sebagai sebuah pisau bermata dua.Pada satu sisi memberikan kelimpahruahan secara material, sedang pada sisi yang lain menciptakan segudang permasalahan yang memprihatinkan terhadap peradaban manusia. ${ }^{5}$ Globalisasi membawa perubahan secara besarbesaran dalam berbagai bidang. Di bidang ekonomi globalisasi membawa perubahan besarbesaran terhadap perluasan pasar, baik pada negara-negara yang sudah maju maupun pada negara-negara berkembang. Perubahan adanya ekspansi pasar di negara-negara industri , membawa dampak perubahan terhadap perilaku konsumtif pada masyarakat diberbagai generasi tanpa memandang pada usia, lapisan masyarakat. Perilaku konsumtip yang berlebihan yang tidak dapat dikendalikan dapat menimbulkan berbagai problem social di masyarakat. Sebagai contoh gaya hidup yang berubah menjadi boros, timbulnya tingkat korupsi dan tingkat kriminalitas yang semakin tinggi.

Globalisasi saat ini ditandai dengan ekspansi pasar di negara-negara industri di dunia . Pada era industri 4.0 yang sedang berlaku membawa perubahan besar terhadap bentuk pemasaran bersama regional seperti AFTA ( Asean Free Trade Area ) yang dibentuk oleh negara-negara Asean untuk menciptakan zona perdagangan bebas, NAFTA ( North American Free Trade ) yang mempunyai tugas mengkoordinasikan kegiatan ekonomi, hubungan niaga,

\footnotetext{
${ }^{5}$ Haru Nugroho, Agenda Aksi Atas Problem Globalisasi Ekonomi, Problema Globalisasi, Surakarta, UNS Perss, 2000, hal 43
} 
komunikasi, kegiatan kebudayaan, kewarganegaraan, paspor dan visa dan kegiatan social dan kesehatan, APEC ( Asia Pasific Economic Coorporation ) yang mempunyai tujuan untuk mengukuhkan pe4rtumbuhan ekonomi, mempererat komunitas dan mendorong perdagangan bebas diseluruh kawasan Pasific dan beberapa organisasi perdagangan dunia lainnya.

Era industri menghasilkan suatu masyarakat industrial ditandai dengan tingkat konsumsi yang tinggi pada masyarakat . Tingkat konsumsi yang tinggi ini dapat membentuk sifat-sifat kontradiktif dan dilematis. Sifat-sifat tersebut dapat menghasilkan suatu masyarakat yang hanya bisa survive dalam kondisi yang kontradiktif dan dilematis ${ }^{6}$. Dinamika proses globalisasi yang berdampak besar pada industri menjadikan kemajuan yang cukup pesat dibidang telekomunikasi berupa internet yang menjadi pilar utama perdagangan nasional maupun internasional. Dampak era revolusi industri 4.0 ini sudah pasti akan menimbulkan suatu era dimana teknologi membawa kita kesuatu dunia yang oleh sementara orang disebut virtualitas berwujud, yang secara fundamental akan mengubah cara hidup, cara bekerja dalam lingkup nasional maupun internasional. Sulit untuk membayangkan kehidupan modern tanpa itu semua saat ini, karena sebuah dunia dengan 1000 lebih negara semua terhubungkan dengan jaringan komputer global, dengan jaringan internet terbesar didunia, semua bekerja sama dan bersaing. Bukan negara-negara yang saling berhubungan, melainkan individuindividu didalam 1000 lebih negara inilah yang saling berhubungan. Bagi sektor industri nasional, revolusi industri memberi peluang percepatan penguasaan teknologi sebagai kunci penentu daya saing dalam kancah perdagangan nasional maupun internasional. Pada era revolusi industri 4.0 dimana penekanan pada pola digital economy, artificial intelligence,big data,robotic atau dikenal dengan fenomena disruptive innovation, ${ }^{7}$ diharapkan mampu menopang pembangunan dibidang perdagangan / bisnis.

Revolusi industri 4.0 yang memberikan suatu perubahan didalam peningkatan konektivitas, peningkatan interaksi dan tidak adanya batas antara manusia, mesin dan sumber daya lainnya, merupakan suatu perubahan dalam perkembangaan teknologi yang akan menciptakan perubahan terhadap cara orang hidup da;am masyarakat, cara mereka bekerja dan menghibur diri mereka sendiri. Bill Gates, presiden Microsft Corp , menggambarkan apa yang sedang terjadi di era industri sekrang ini sebagai penciptaan

\footnotetext{
${ }^{6}$ Heru Nugroho, ibid, hal 50

${ }^{7}$ Nasir, Era Revolusi Industri 4.0
} 
sebuah "tatanan dunia digital yang baru" ini adalah revolusi teknologi yang akan meningkatkan kehidupan kita ${ }^{8}$

Pada awal april 2018, Pemerintah membuat sebuah strategi pada industri nasional, khususnya dalam menghadapi era revolusi industri 4.0 yaitu memfokuskan inovasi pada kekuatan ekonomi pada industri makanan dan minuman, elektronik, otomotif, tekstil dan kimia serta pencanangan "10 Bali Baru" yaitu peningkatan pada industri hasil pekerjaan tangan, kerajinan tangan, industri kreatif dan wisata sebagai penyumbang ekonomi global yang tidak ada tandingannya. Prof Dr.John Pieris berpendapat bahwa Revolusi Industri 4.0 muncul bersamaan dengan penggunaan ilmu dan Teknologi Informasi (TI) secara luas akan membawa perubahan terhadap pola pikir, pola kerja, dan pola hidup warga negara diberbagai negara , dimana manusia tetap berposisi sebagai subyek dari perkembangan peradaban baru berbasis revolusi industri 4.0. Menurut beliau Revolusi Industri 4.0 memiliki 4 (empat) ciri yakni : (1) simple atau sederhana karena tidak rumit, (2) proses yang cepat/ faster, dapat dilakukan sewaktu-waktu kapan saja dan menjangkau diantara negara-negara, (3) biaya yang lebih ringan/ lebih murah / cheaper dan (4) dapat diakses dengan mudah /accessible. ${ }^{9}$

Era industri 4.0 menghasilkan pabrik cerdas dengan penggunaan lewat internet ofThing (IoT) dengan segala sistem elektronik yang aman, andal, beroperasi sebagaimana mestinya, dan bertanggung jawab. Hal ini untuk mencegah (menghindari, meminimalkan) perbuatan melawan hukum yang dapat menimbulkan kerugian. Tujuannya adalah untuk memberikan jaminan kepastian hukum dan manfaat ( keadilan ) yang dilandasi oleh prinsip kehati-hatian dan itikad baik. $^{10}$

Transaksi elektronik pada era industri 4.0 merupakan model bisnis modern yang berbeda dengan bisnis yang biasa dilakukan secara konvensional dimana pada era ini dalam melakukan perjanjian dengan pihak lain dapat dilakukan secara non-face ( tanpa menghadirkan pelaku bisnis secara fisik ), non-sign ( tidak memakai/ menggunakan tanda tangan asli atau tanda tangan basah ), dan lebih praktis karena tanpa menggunakan kertas ( paperless ). Aspek positip transaksi elektronik dianataranya adalah dapaat menjadi penggerak kegiatan bisnis yang dapat memberi keuntungan dalam peningkatan dibidang ekonomi. Akan tetapi tidak menutup kemungkinan munculnya aspek negative dari perkembangan industri ini

\footnotetext{
${ }^{8}$ John Naisbitt, Global Paradox, Megatrends, 2000 , Binarupa Aksara, Jakarta. hlm 93.

9 Prof.Dr.John Piers SH.MH dosen Pasca Sarjana Universitas Kristen Indonesia (UKI) Jakarta, 2018, Kecerdasan Hukum Respons Revolusi Industri 4.0. Jurnal Stagingpoint.

${ }^{10}$ Dhanang Widijawan, e-Logistics Contract, Tanggung jawab pelaku usaha terhadap malfunction, keamanan siber dan data pribadi, Keni Media, Bandung, 2017, hal 119
} 
yaitu berkaitan dengan persoalan keamanan dalam bertransaksi, munculnya bentuk penyelewengan-penyelewengan yang menimbulkan kecenderungan kerugian bagi konsumen dan timbulnya berbagai permasalahan hukum didalam transaksi elektronik.

Pemerintah menyadari bahwa pemanfaatan teknologi informasi perlu diatur dalam sebuah aturan hukum demi menciptakan kepastian hukum dalam melakukan kegiatan usaha. disatu pihak dan mengantisipasi munculnya penyalahgunaan teknologi informasi sebagai sarana untuk melakukan kejahatan melalui dunia maya ( cyber crime) di lain pihak. Sebagaimana penjelasan undang-undang Nomor 11 Tahun 2008 Tentang Informasi dan Teknologi Elektronik ( ITE ) disebutkan bahwa perkembangan dan kemajuan teknologi informasi dan komunikasi telah menyebabkan perubahan kegiatan kehidupaan manusia dalam berbagai bidang dan terjadinya hubungan dunia menjadi seolah-olah tanpa batas ( bordeless ) yang menyebabkan perubahan secara significant terhadap kegiatan social, ekonomi, dan budaya .

Dinamika pembangunan yang dipicu oleh kemajuan pada trend global sangat berpengaruh terhadap tatanan hukum, sehingga harus dicermati secara kritis dan inovatif terhadap pembangunan hukum . Pada realitas hukum yang ada, seberapa efektifkah undangundang ITE dan peraturan hukum nasional Indonesia lainnya yang mengatur tentang hukum bisnis mampu menjadi benteng pertahanan atas perilaku aktifitas-aktifitas dalam dunia maya. Sebab aktifitas-aktifitas di dunia nyata sangat berbeda dengan aktifitas-aktifitas di dunia nyata, sehingga apakah hukum konvensional yang mengatur tata hubungan didunia nyata dapat diterapkan untuk mengatur aktivitas-aktivitas di dunia maya apalagi ketika melewati yuridiksi nasional.

Suasana perubahan "menjadi trend global" tersebut sangat mempengaruhi perkembanagan dalam hukum nasional, dimana munculnya beberapa pertanyaan antara lain: ${ }^{11}$

a. Bagaimana bidang hukum makin mengalami internasionalisasi

b. Bagaimana arena transnasional dalam praktek pemciptaan hukum

c. Bagaimana kekuatan-kekuatan dan logika-logika yang bekerja dalam bidang ekonomi bagi tatanan kepentingan negara dan tatanan internasional terhadap hukum untuk mampu memberikan suatu logika dibidang hukum dari suatu fenomena yang lebih besar.

\footnotetext{
11 Satjipto Rahardjo, Problem Globalisasi Perspektif sosiologi hokum, ekonomi dan agama, Pembangunan Hukum di Indonesia dalam konteks situasi global. Muhammadiyah University Press, 2001 hal 3.
} 
Hukum sebagai penggerak pembangunan, pada dasarnya merupakan suatu usaha untuk membangun hukum dalam konteks yang lebih besar, baik melalui peninjauan kembali huokum yang sudah ada dan menyelenggarakan sistem hukum baru secara sistematis dan berencana untuk membangun suatu tata hukum yang mewujudkan cita hukum sesuai dengan apa yang terkandung dalam Undang-undang Dasar dan Pancasila. Lili Rasjidi dan IB Wyasa Putra mengemukakan bahwa pembangunan hukum dilakukan untuk membangun system hokum untuk menempatkan Indonesia ditengah-tengah peta global dan menjalankan perannya dalam situasi global dengan melalui pembaharuan hukum yang dapat berbentuk rekonstruksi hukum, intensifikasi dan pengembangan fungsi hukum melalui penataan, pengelolaan dan pengembangan hokum. ${ }^{12}$ Untuk mewujudkan kemakmuran dan kebahagiaan masyarakat melalui keadilan dan ketertiban dalam upaya pemerataan, pertumbuhan dan perluasan kegiatan perekonomian nasional maupun internasional yang dilakukan melalui kebijakan bisnis yang diarahkan pada peningkatan iklim usaha perdagangan ( persaingan usaha yang sehat ) secara efisien dan efektif.

Indonesia ditengah-tengah peta global seiring dengan perubahan dan perkembangan tersebut , Indonesia makin terkooptasi dalam ekonomi global . Sebagai konsekuensinya maka harus tentunya harus banyak melakukan penyesuaian yang semula hanya sebatas memenuhi kebutuhan komunitas-komunitas lokal yaitu sebagai pengontrol ketertiban kehidupan bermasyarakat dan bernegara ke fungsinya yang lebih besar yaitu harus siap berdinamika di kancah ruang lingkup global ( pasar-pasar yang kian bersifat abstrak) ${ }^{13}$ Implikasi semua itu sangat mendasar dalam konteks pembangunan hukum nasional dimasa mendatang, oleh karena itu berkaitan dengan hal tersebut terdapat dua hal :

a. Hubungan moral antara warga negara dengan hukum ( negara )

b. Kemampuan sistem hukum dan sistem politik kita di dalam memenuhi tuntutan rakyat akan keadilan. ${ }^{14}$

Era revolusi industri membawa pada perkembangan dan perubahan di berbagai bidang, baik social, ekonomi, hokum dan bidang lainnya . Di bidang sosial revolusi industri sosial menbawa perubahan-perubahan kehidupan dibidang hukum dan perdagangan / bisnis baik secara sederhana namun gamblang sampai kepada bentuk organisasi-organisasi kehidupan

\footnotetext{
${ }^{12}$ Rasjidi, Lili dan IB Wyasa Putra, Hukum sebagai suatu system, Bandung, Mandar Maju, 2003, hal 179.

${ }^{13}$ Soetandyo Wignjosoebroto, Perkembangan hokum dan antisipasinya menghadapi perkembngan bisnis pada era nasional dan global,UMS Perss, 2001, hal 21.

${ }^{14}$ Nasikun, Globalisasi dan problematika pembangunan hokum suatu tinjauan sosiologis, hal 33
} 
baru yang pada awalnya dalam skala dan formatnya nasional berlanjut ke skala dan formatnya yang global. Sebagai akibat dari globalisasi maka menimbulkan perubahan tata nilai dalam kehidupan masyarakat dalam berbagai problematika . Oleh karena itu perlu diatur oleh aturaan hokum sebagai law making dan perlu penegakan hukum sebagai law inforcement.

Pembangunan materi hukum dalam menghadapi tantangan industri 4.0 diarahkan untuk melakukan pembaharuan dan pembentukan produk hukum baru khususnya dibidang perdagangan / bisnis yang mencerminkan nilai-nilai Pancasila dan UUD 1945 . yang didasarkan pada kebutuhan masyarakat. Untuk mengikuti perkembangan dan dinamika pembangunan yang sesuai dengan aspirasi masyarakat baik kebutuhan masa kini maupun masa depan dalam mendukung era revolusi industri 4.0. dengan menekankan pada pentingnya substansi hukum yang meliputi ${ }^{15}$ :

Pertama, hukum bukan sekedar merupakan alat bantu untuk mencapai rasionalitas, akan tetapi produk hukum itu sendiri harus bersifat rasional. Hukum yang rasional adalah produk hukum yang benar-benar mampu mewujudkan tujuan kehadirannya, yaitu diperlukan untuk bertindak terhadap kepentingan mereka sesuai dengan amanat yang ada di dalam UUD 1945, tujuan hukum yaitu untuk melindungi segenap bangsa Indonesia dan seluruh tumpah darah Indonesia, mewujudkan keadilan sosial bagi seluruh rakyat Indonesia.Kedua, menjamin agar produk hukum yang bersifat rasional tersebut dapat mewujudkan tujuan hukum, dengan dukungan dari perangkat pelaksanaan hukum.Ketiga, pentingnya substansi dalam proses pembentukan hukum, dalam kaitannyaa dengan pengaruh struktur social masyarakat dimana produk hukum yang seharusnya dalam mewujudkan tujuan-tujuannya.

Pembangunan hukum harus mewujudkan pada cita-cita bangsa yaitu mewujudkan masyarakat adil dan makmur berdasarkan Pancasila . Nilai-nilai Pancasila dengan berbasis moral agama, menghargai dan melindungi hak asasi manusia tanpa diskriminasi, mempersatukan seluruh unsur bangsa dan membangun keadilan sosial di bidang ekonomi maupun kemasyarakatan dalam mewujudkan kedaulatan rakyat dan kedaulatan hukum dalam membangun konsep pembangunan hukum berskala nasional dan internasional. Dalam pembangunan hukum internasional khususnya dalam bidang perdagangan/ bisnis yang menyeluruh dan multidisipliner dalam meningkatkan daya saing di kancah perdagangan internasional untuk tujuan bagi kesejahteraan masyarakat. Pembangunan hukum dalam

\footnotetext{
${ }^{15}$ Nasikun, Ibid, hal 34
} 
perspektif Pancasila dalam menuju peradaban masyarakat bermartabat akan dihadapkan pada berbagai tantangan dan pengaruh ideologi asing maka pembangunan hukum nasional harus mampu mengatasi dan memenuhi tuntutan globalisasi dan regionalisasi sekaligus untuk meningkatkan daya saing produk-produk Indonesia. Pemerintah harus secara terus menerus mengevaluasi semua peraturan perundang-undangan yang terkait dengan bidang perdagangan. Pembangunan hokum dalam perspektif Pancasila harus menjadi pegangan dalam melakukan transaksi, atau kerjasama antara modal nasional dengan modal asing yang harus memenuhi aspek-aspek : (a) adanya unsur asing / internasional dalam melakukan kerjasama, (b) penggunaan bahasa hukum, untuk memberikan penafsiran yang sama (c) klausula-klausula yang berbeda dengan sistem hukum internasional.

Dalam rangka mewujudkan arah kebijaksanaan tersebut diatas, dalam bidang pembaharuan peraturan perundang-undangan diharapkan dapat terciptanya harmonisasi hukum yang sesuai dengan aspirasi masyarakat dan kebutuhan pembangunan hukum dibidang perdagangan. Banyak faktor yang mempengaruhi terjadinya perubahan hukum dalam suatu negara pada era industri ini baik yang berasal dari dalam negeri ( internal ) yang membawa perubahan yang cepat dan radikal yang mempengaruhi system hukum yang sedang berjalan dan factor yang berasal dari luar ( eksternal ) sebagai suatu proses penyesuaian hukum nasional terhadap hukum internasional.

Indonesia yang menjadi bagian dari proses globalisasi ekonomi di era industri 4.0 , khususnya dalam proses restrukturisasi ekonomi global tentunya harus mampu mempersiapkan diri dalam menghadapi ekonomi global yang sedang berlangsung saat ini. Pemerintah harus mampu secepatnya menghilangkan kelemahan-kelemahan di bidang eksport maupun dibidang import serta mengembangkan potensi ekonomi untuk mengembangkan potensi eksport dan untuk mengurangi import. Pemerintah harus memperkokoh daya tahan ekonomi domestic dari serangan baru ekonomi asing. Pemerintah mempunyai tanggung jawab dalam meningkatkan daya saing produk-produk Indonesia dan mempunyai konsekuensi harus segera melakukan penataan hukum agar tidak menghambat proses reformasi global. Kita tidak boleh setengah hati dalam melakukan pembangunan dan pembaharuan hukum dalam menghadapi perdagangan di era industri 4.0 ini. Pembangunan hukum yang dilakukan harus berlandaskan pada Undang-Undang Dasar 1945 dan Pancasila untuk memberikan perlindungan hukum terhadap praktek-praktek perdagangan yang merugikan negara dan konsumen serta sebagai suatu upaya dalam menciptakan kemakmuran yang sebesar-besarnya 
bagi seluruh rakyat Indonesia. Pembangunan hukum berbasis Pancasila harus menjadi pegangan dalam melakukan transaksi-transaksi dan memastikan semuanya taat pada hukum. Diharapkan semua negara dengan produk hokum / aturan yang berbeda mampu merumuskan pada satu produk hukum bersama sehingga tidak ada yang dirugikan dalam kegiatan perdagangan/ bisnis yang sudah menjangkau pada negara-negara di dunia.

\section{PENUTUP}

Peranan hukum dalam kegiatan perdagangan/bisnis sudah diatur dalam berbagai peraturan perundang-undangan baik peraturan yang berlaku bagi pelaku usaha maupun konsumen dalam memberikan perlindungan hokum bagi kedua pihak. Pembangunan hukum yang dilakukan baik melalui rekonstruksi maupun harmonisasi antara kemajuan teknologi dan regulasi yang sudah ada maupun yang akan dibuat selayaknya dapat memberi kemanfaatan yang positip dengan membingkainya dalam hukum yang sesuai dengan nilai-nilai Pancasila, harus mampu memberikan perlindungan baik terhadap praktek-praktek perdagangan yang merugikan dan perlindungan terhadap konsumen.

\section{REFERENCES}

Ernawan,Erni R. 2007. Business Ethics.Bandung: Alfabeta.

Fens Alwino. 2018. Kecerdasan Hukum Respons Revolusi Industri 4.0. http://stagingpoint.com/read/2018/11/14/151205/Kecerdasan.Hukum.Respons.Revolusi.Industri.4.0.

Haru Nugroho.2000.Agenda Aksi Atas Problem Globalisasi Ekonomi, Problema Globalisasi. Surakarta: UNS Press.

Naisbitt, John. 2000. Global Paradox, Megatrends. Jakarta: Binarupa Aksara.

Nasikun. 2001.Globalisasi dan problematika pembangunan hokum suatu tinjauan sosiologis. Surakarta: UNS Press.

Nasir. 2018. Era Revolusi $\quad$ Industri $\quad$ 4.0. http://sumberdaya.ristekdikti.go.id/index.php/2018/01/30/era-revolusi-industri-4-0saatnya-generasi-millennial-menjadi-dosen-masa-depan/.

Rahardjo, Satjipto. 2001. Problem Globalisasi Perspektif sosiologi hokum, ekonomi dan agama, Pembangunan Hukum di Indonesia dalam konteks situasi global. Surakarta: Muhammadiyah University Press.

Rasjidi, Lily dan IB Wyasa Putra. 2003. Hukum Sebagai Suatu System. Bandung: Mandar Maju. 
Sanusi,M Arsyad. 2010. Antisipasi cybercrime dan efektivitas UU ITE. Jurnal Hukum Bisnis, Vol 29 Tahun 2010.

Toynbee, Arnold. 1884. Lecturer on the Industrial Revolution, London.

Widijawan, Dhanang. 2017. e-Logistics Contract, Tanggung Jawab Pelaku Usaha Terhadap Malfunction, Keamanan Siber Dan Data Pribadi. Bandung:Keni Media.

Wignjosoebroto, Soetandyo. 2001. Perkembangan Hukum Dan Antisipasinya Menghadapi Perkembngan Bisnis Pada Era Nasional Dan Global. Surakarta: Muhammadiyah University Press. 